administered by continuous infusion to guinea-pigs by a method similar to one used by Sekiya and Vaughan Williams (3). Guinea-pigs of both sexes weighing between 250 and $600 \mathrm{~g}$ were used. The animals were anaesthezed with $25 \%$ urethan solution in a dose of $0.7 \mathrm{ml} / 100 \mathrm{~g}$ of both weight. A polyethylene cathetcr was introduced into the jugular vein and ouabain was administered by infusion through the canula with the help of a continous infusion machine at a rate of $5 \mathrm{mcg}$ at every 1.5 minutes with a gap of one minute in between each infusion. Occurrence of ventricular fibrillation or cardiac arrest was taken as the end point.

The observations are depicted in Table 1.

In the experiments, it has bcen seen that when the animals were treated with $5 \mathrm{mg} / \mathrm{kg}$ of reserpine 24 hours before, they died of cardiac arrest instead of ventricular fibrillation. However, this effect was not observed when the animals were treated with reserpine just at the start of ouabain infusion or when reserpine was administered after $40 \%$ lethal dose of ouabain. From these it may be concluded that the modification of the cause of digitalis intoxication seen after 24 hours of treatment with reserpine, was due to deplction of cardiac catecholamines. This confirms the carlier observations of Erlij and Mendez (4) but is in variance with those of Takagi et al. (5).

The beta-adrenergic blocking agent propranolol but not INPEA, modificd the modc of death after ouabain. It is thus logical to assume that the absence of ventricular fibrillation induccd by propranolol is not due to its beta adrenergic blocking activity. However, neither it could be attributed to a 'quinidine like' effect since quinidine itself did not modify the mode of death after ouabain. It is, therefore, likely that propranolol affected ouabain induced ventricular fibrillation via some mechanism other than beta-adrenergic blockade or non-specific 'quinidine like' effect. In this context reference may be made to i) the local anaesthetic action of propranolol (Sekiya and Vaughan Willams (3)), ii) the proposed neural action (Standeaert el al. (6)) or iii) the possibility of direct pharmacological antagonism to ouabain (Tuttle and Innes (7)).

\title{
REFERENGES
}

1) Szekers, L.: Biochem. Pharmac. 12, 168 (1963); 2) Mendez, C., Acheves, J. And Mendez, R.: J. Pharmac, exp. Ther. 131, 191 (1961); 3) SekiYa, A. and Vaugilan Wirt.tams, E.M.: Br. J. Pharmac. Chemother. 21, 462 (1963); 4) Erlij, D. and Mendez, R:: J. Pharmac. exp. Ther. 144, 97 (1964); 5) Takagi, M., Zanuttini, D., Khalis, E. and Bellet, S.: Am. J. Cardiol. 15, 203 (1965); 6) Standeafrt, E.G., Levitt, B. and Roberts, J.: Nature, Lond. 210, 742, (1966); 7) Tuttle, R.R. And Innes, I.R.: J. Pharmac. exp. Ther. 153, 211 (1966)

\section{INTERAGTION BETWEEN EXTRACELLULAR SODIUM AND THE EXCITATORY EFFECT OF ACETYLCHOLINE ON THE NON- PACEMAKER POTENTIAL ARRESTED BY PROPRANOLOL IN THE ISOLATED RABBIT'S ATRIA}

\author{
TAKAO KUBO AND YOSHIMI MISU \\ Department of Pharmacology, Faculty of Pharmaceutical Sciences, Kyoto University, Sakyo-ku, Kyoto
}

Rccived for publication June 13, 1969

An excitatory effect of acetylcholine (ACh) on the non-pacemaker potential arrested by high doses of the adrenolytics was obscrved previously in the isolated rabbit's atria (1). In present experiments, interaction 久保 奖夫.三須 良実 
between cxtraccllular sodium $(\mathrm{Na})$ concentration and the excitatory effect of ACh was investigated in the isolated rabbit's atria.

Rabbits of either sex weighing from 2.0 to $3.0 \mathrm{~kg}$ were used. Isolated atria were maintained in RingcrLocke's solution bubbled with $95 \% \mathrm{O}_{2}$ and $5 \% \mathrm{CO}_{2}$ at $30^{\circ} \mathrm{C}$. Non-pacemaker potentials of spontaneously beating atria were recorded intracellularly in almost the same manner as previously described (1).

Propranolol $\left(10^{-5} \mathrm{~g} / \mathrm{ml}\right)$ decreased gradually the resting potential, the rate of rise of depolarization phase and the height of overshoot, and prolonged the repolarization time of the action potential, and arrested the non-pacemaker action potential about 60 minutes after it's application (Fig. 1A, A-C). ACh $\left(10^{-6}\right)$ could

A

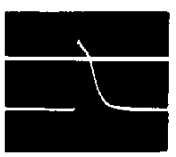

A

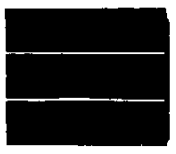

E

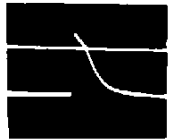

A

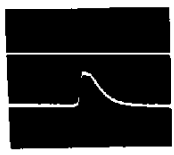

E

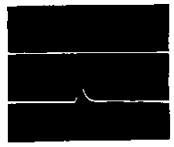

F

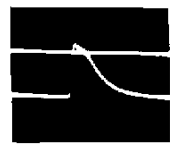

B

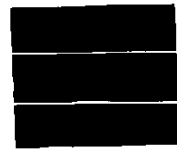

C

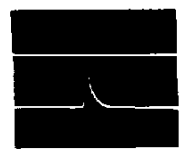

6

B

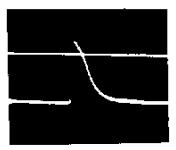

c

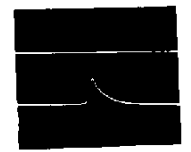

[)
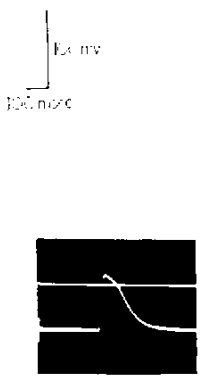

D

b

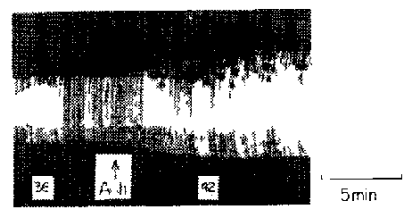

FiG. 1A. Effect of propranolol (A-C) and the evoking effect of ACh in the presence of propranolol (D-G) on the non-pacemaker transmembrane potential of the rabbit's atria.

A : before, B: 40 minutes after propranolol $\left(10^{-5}\right), C: 60$ minutes after, D: 1 minute after the first addition of $\mathrm{ACh}\left(10^{-6}\right), \mathrm{E}: 3$ minutes after, $\mathrm{F}: \mathrm{l}$ minute after the addition of $\mathrm{ACh}\left(10^{-6}\right)$ and $\mathrm{NaCl}$ (30 mu), $G$ : 15 minutes after.

B. Effect of ACh on the rabbit's atria in low sodium Ringer-Locke solution.

a. The non-pacemaker potentials.

A : before, $B$ : 30 minutes after the replacement of 60 percent of $\mathrm{NaCl}$ in Ringer-Locke solution by sucrose, $\mathrm{C}: 8$ minutes after $\mathrm{ACh}$ $\left(10^{-7}\right)$, D : 1 minute after atropine $\left(10^{-6}\right)$ in the presence of $\mathrm{ACh}$.

b. The contractile amplitude.

Numerals below the record show atrial frequencies (beats/min). Each recording of the transmembrane potentials in Fig. $1 \mathrm{~A}, \mathrm{~A}-\mathrm{G}$ and Fig. 1B, B-D was performed in the same single cell. 
temporarily evoke the action potentials arrested by propranolol, but in the normal nutrient solution (154 mM external $\mathrm{Na}$ ) the complete recovery in both the rate of rise and amplitude of the action potential could not be obtained cven by repetitive additions of $\Lambda$ Ch (Fig. 1A, D-E). However, simultaneous addition of the same single dose of $\mathrm{ACh}$ and $30 \mathrm{~mm}$ of external $\mathrm{Na}$ (totally $184 \mathrm{~mm}$ ) could result in the more complete recovery of these parameters and moreover continuous firing of the action potentials (Fig. $1 \Lambda, F-G$ ). On the other hand, contraction of rabbit atria arrested by propranolol $\left(10^{-5}\right)$ was partially recovered by the addition of ACh $\left(10^{-6}\right)$ or/and $77 \mathrm{~mm} \mathrm{NaCl}$ (totally $231 \mathrm{~mm}$ ).

When sixty percent of the external $\mathrm{NaCl}$ was replaced by an isoosmotic amount of sucrose in untreated atria, action potential showed a decrease in both the ratc of rise and the height of overshoot without markedly changing the resting potential (Fig. 1Ba, A-B). The decrease in both the heart-rate and the contractile amplitude was also observed. ACh $\left(10^{-7}\right)$, applied 30 minutes after changing the solution, could restore completely these parameters without marked changing of the resting potential (Fig. 1Ba, C). The contractile amplitude, in both spontaneously beating atria and electrically driven atria (40 beats/min), was also recovered by $\mathrm{ACh}\left(10^{-7}\right)$ (Fig. $\left.1 \mathrm{Bb}\right)$, the effect of which was blocked by the addition of atropine $\left(10^{-6}\right)$ (Fig. 1Ba, D).

Morales-Aguilera and Vaughan Williams (2) have shown that propranolol reduced the rate of entry of depolarizing current. Johnson and Robertson (3) proposed the following hypothesis that ACh restarted an atrium arrested by quinidine by the direct effect on the "sodium carrying system". Further cvidence for these hypotheses was presented by this experiment. The excitatory effect of $\Lambda$ Ch might be due to a direct improvement on the "sodium carrying system" in the condition of low sodium availability in addition to the indirect recovery resulted from the slight restoration of the resting potential by increasing permeability to potassium.

\title{
REFERENCES
}

1) Misu, Y., Tanaka, C. and Takaort, S.: Jap. J. Pharmac. 15, 176 (1965); 2) Morales-Aguilerá, A. and Vaughan Williams, E.M.: Br. J. Pharmac. Chemother. 24, 332 (1965); 3) Johnson, E.A. and Robertson, P.A.: Br. J. Pharmac. Chemother. 13, 304 (1958)

\section{ANTAGONISM OF IMIPRAMINE INDUCED FATAL HYPERPYREXIA IN MAO INHIBITOR TREATED RABBITS}

\author{
J.N. SINHA, K.M. DHASMANA, K.S. DIXIT AND K.P. BHARGAVA \\ Department of Pharmacology \& Therapeutics, K.G's Medical College Lucknow-3, India \\ Received for publication June 23, 1969
}

Extensive use of monoaminc oxidase inhibitors and imipramine in psychiatric practice has revealed serious toxic reactions. It has been observed that combination of monoamine oxidase inhibitor and imipramine produces a symptom complex characterized by hyperexcitement, motor restlessness and hypcrpyrexia (1-6). Furthermore, hypertensive crisis, subarachnoid haemorrhage and pulmonary oedema has been reported to occur in patients who were maintained on monoamine oxidase inhibitor and took cheese or broad bcans $(7,8)$. High contents of tyramine in cheese and 3-4 dihydroxyphcnylalanine (dopa) in broad beans have been suggested to be responsible for the above mentioned serious side effects. Since it is known that in MAO inhibitor pretreated aninals administration of both, tyramine and dopa increase circulating catecholamine content 